\title{
Proxy development: a new facet of morphological diversity in the marine diatom Eucampia antarctica (Castracane) Mangin
}

\author{
CLAIRE S. ALLEN \\ British Antarctic Survey, High Cross, Madingley Road, Cambridge CB3 0ET, UK \\ (e-mail: csall@bas.ac.uk)
}

\begin{abstract}
The varied aspect ratios observed in the Antarctic marine diatom Eucampia antarctica are described and quantified. Data are compiled from detailed measurements of the gross morphology of winter stage specimens found in samples of modern marine sediments. Surface sediment samples come from a range of oceanographic settings spanning almost $20^{\circ}$ of latitude from north of the Polar Front in the SW Atlantic to close to continental Antarctica in the southern Amundsen Sea. Results are compared with previously recorded morphological data ascribed to the polar and sub-polar varieties of E. antarctica (E. antarctica var recta and E. antarctica var antarctica) and reveal that the aspect ratio of both varieties responds independently of symmetry and colony structure. The discussion considers the likely basis of the observed aspect ratio distribution and whether the morphological diversity offers any potential for use as proxy evidence in Antarctic palaeoceanographic reconstructions. Although it requires further study, valve symmetry offers promising potential as a quantitative proxy for austral summer sea surface temperatures.
\end{abstract}

KEYWORDS: morphology, marine diatom, Antarctic, Eucampia antarctica, palaeoceanographic proxy

\section{INTRODUCTION}

Palaeoclimatic reconstructions are an essential component of climate research, revealing the Earth's varied climatic history and providing the empirical data for testing the validity of modelled climate systems. Developing our understanding of existing proxies and assessing the potential of new proxies is an important aspect of this research. In the Southern Ocean where carbonate preservation is scarce, diatoms are particularly useful for palaeoclimatic/ palaeoceanographic reconstructions as they are diverse, abundant and well preserved. Although diatom-based reconstructions rely principally on species relative abundance data, previous studies have provided good evidence that infraspecific morphological variation ('polymorphism') can be used as an additional palaeoenvironmental proxy (Fryxell, 1988; 1994; Cortese \& Gersonde, 2007).

Although few Antarctic diatoms produce true resting spores, summer/winter and cold/warm water forms appear to be common amongst Antarctic diatom species and are usually morphologically distinct. These growth forms are probably an important adaptation to survive the extreme seasonality of the polar regions and transitions between these growth forms (resting spores, winter/summer, cold/warm water forms) are likely to be environmentally triggered (Palmisano \& Sullivan, 1983; Doucette \& Fryxell, 1985; Ligowski et al. 2012). Studies have already shown the proxy potential of these growth stages in several Antarctic marine diatoms (Leventer et al. 2002; Taylor \& Sjunneskog, 2002). Nitrogen depletion is suggested as an important resting state trigger for Thalassiosira antarctica Comber and Chaetoceros Ehrenberg subgenus Hyalochaete Gran (Peters \& Thomas, 1996; Ishii et al. 2011) whilst in other species, temperature, salinity, nutrient availability and light intensity may be the principal controls over different growth forms. The warm- and cold-water forms of $T$. antarctica are morphologically distinct, with different areolae sizes, cell sizerange and silicification, that have been related to water temperature and ice formation and yield additional proxy tools for Antarctic palaeoceanographic reconstructions (Villareal \& Fryxell, 1983; Doucette \& Fryxell, 1985; Buffen et al. 2007).
Morphological variety in the endemic Antarctic marine diatom Eucampia antarctica already provides a useful palaeoceanographic tool of relative temperature. Fryxell (1991) shows that the two morphologically distinct varieties $E$. antarctica (Castracane) Mangin var antarctica and E. antarctica var recta (Mangin) Fryxell \& Prasad inhabit different oceanographic regions. The nominate variety, characterized by long chains $(10+$ cells) of asymmetrical valves, is found in the sub-polar plankton and sediments north of the Polar Front, whilst E. antarctic var recta, with short chains (typically 2-4 cells) of symmetrical valves, inhabits areas within the seasonal sea-ice zone and cold waters close to the Antarctic continent. Down-core variations in the ratio of the two varieties are used to infer relative temperature change. Fryxell (1991) also suggests that the aspect ratio of the $E$. antarctica valves is a feature of the same phenotypic response. Here I present morphological evidence from a range of sites throughout the Antarctic Peninsula (AP) and Scotia Sea to assess whether the aspect ratio varies in tandem with temperature and matches the changes in gross colony morphology.

\section{Previous studies}

Polymorphism is recognized in many diatoms and may reflect greater genetic diversity within a morphologically defined species (morphotype) (Beszteri et al. 2007; Poulíčková \& Hašler, 2007; Bruder \& Medlin, 2008; Balzano et al. 2011). The most common and obvious changes occur in the valve structure and ornamentation, such as the valve shape and size, valve symmetry, silicification and areolation pattern. Changes in the cell morphology over time may be in response to environmental or evolutionary conditions. Morphological changes over long time periods $\left(\geq 10^{5}\right.$ years) are attributed to evolutionary adaptation, whilst morphological transformations over short time frames $\left(\leq 10^{4}\right.$ years $)$ are more likely to be a response to environmental dynamics, e.g. variations in temperature, salinity, nutrient or light availability. Where an organism is able to alter its observable characteristics in response to a change in the environment, it is referred to as "phenotypic 
a)

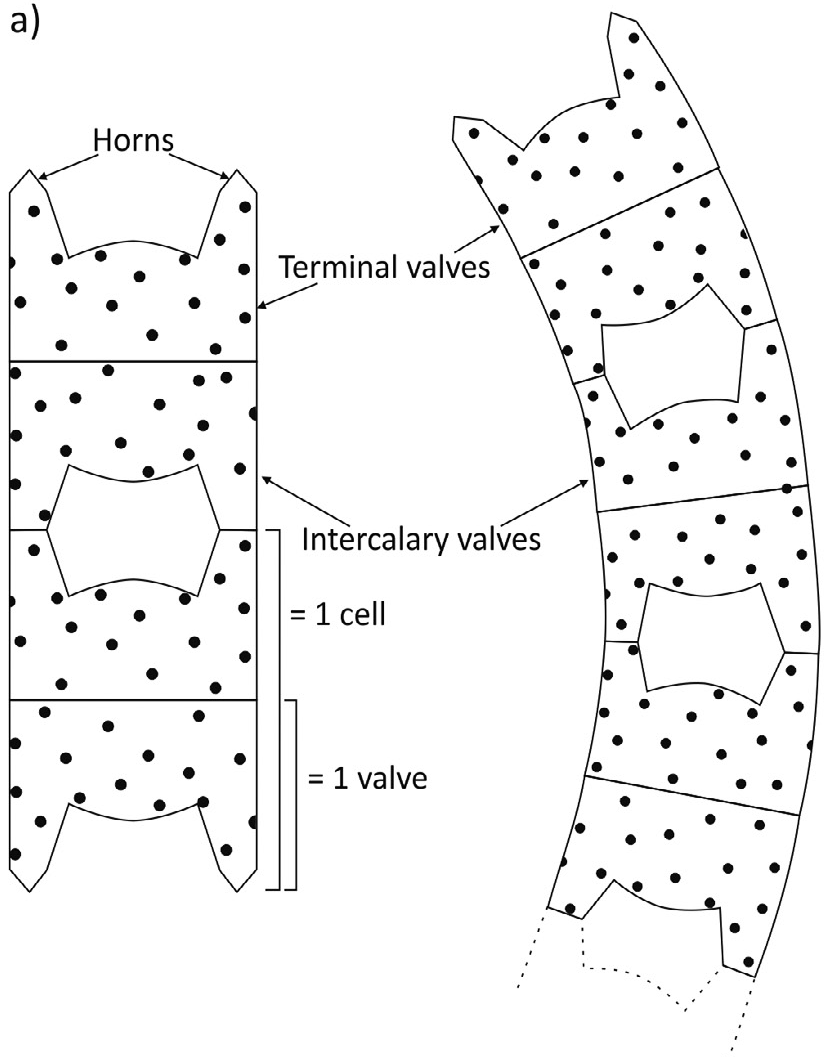

b)
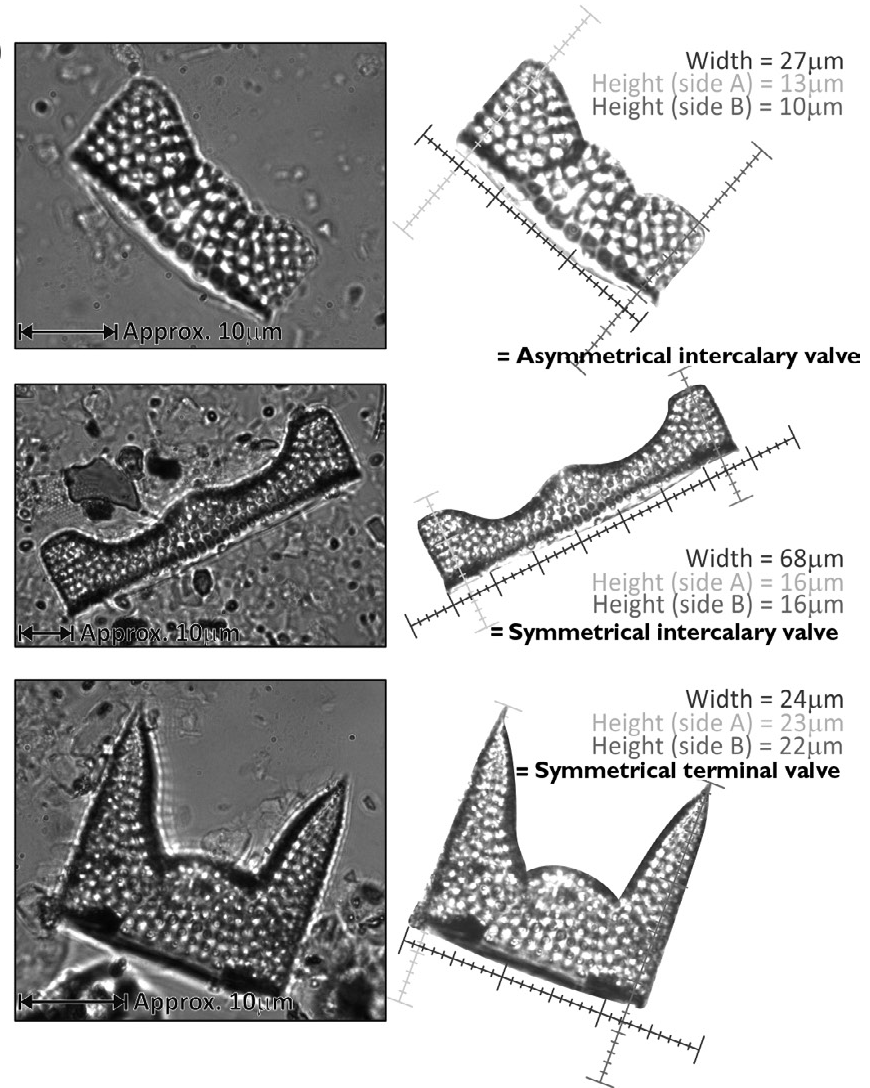

Fig. 1. Morphological structure and measurements. (a) Schematic drawing of colony structures of Eucampia antarctica indicating position of terminal and intercalary valves. The straight colonial form with symmetrical valves (left) is E. antarctica var. recta and the curved form comprised of asymmetrical valves (right) is E. antarctica var. antarctica (after Whitehead et al. 2005). (b) Illustration of valve measurements taken from light microscope images from different shaped Eucampia antarctica valves.

plasticity' and it is this type of polymorphism that holds the most potential for developing morphological proxies.

Several studies show that environmental conditions exert control over various aspects of valve morphology. In one of the early culture studies, Paasche et al. (1975) show that changing salinity causes variation in osmotic pressure that affects the length of siliceous processes in Skeletonema subsalsum (A. Cleve) Bethge. Similarly, Cattaneo et al. (2004) note a strong statistical relationship between valve length and metal contamination in diatoms from Lac Dufault (Québec, Canada). More recently, Balzano et al. (2011) investigated the impact of variable salinity across ten strains of Skeletonema and found evidence of morphological responses and diverse tolerances, even within species. These studies are usually concerned with monitoring water quality and understanding the potential legacy of pollution, so rarely include Antarctic diatom species.

\section{Eucampia antarctica}

E. antarctica exhibits heteromorphy related to both cell position within the colony and environmental responses (Fryxell \& Prasad, 1990). Fryxell (1991) summarizes observations of E. antarctica prior to 1991 and describes the two morphological variants of $E$. antarctica (var antarctica and var recta) in the context of their distribution in the waters and sediments of the Kerguelen Plateau and Prydz Bay. E. antarctica var. recta has symmetrical valves that create straight chains, short colonies (Fig. 1a), and is considered the 'true polar' variety associated with extremely cold, icecovered waters and areas close to the continent. E. antarctica var. antarctica is characterized by asymmetrical valve shapes that produce spiralling chains (Fig. 1a) that tend to have many more cells than the colonies of the 'recta' variety. E. antarctica var antarctica is found in association with warmer waters of the Polar Front Zone (PFZ) and Subantarctic Zone (SAZ). In both varieties the terminal valves are distinguished by pointed 'horns' in contrast to the flattened horns found on the intercalary valves (Fig. 1a). The ratios of terminal and intercalary valves of the summer and winter forms are used to estimate colony length and rates of cell division and are found to be consistent with the environmental associations inferred from the cell symmetry (Fryxell, 1991; Kaczmarska et al. 1993). Fryxell (1991) also calculates valve volumes for the two samples and notes that, together, the valve widths and volumes form a continuum rather than two independent populations, with valves from Prydz Bay expanded in the upper size range. Fryxell (1991) suggests that the larger cell size of the polar variety is another distinctive feature of the E. antarctica var recta morphotype. Although the ratio of $E$. antarctica's valve symmetry and colony structure is now used in palaeoceanographic studies as a proxy for relative sea surface temperature (SST) (Leventer et al. 

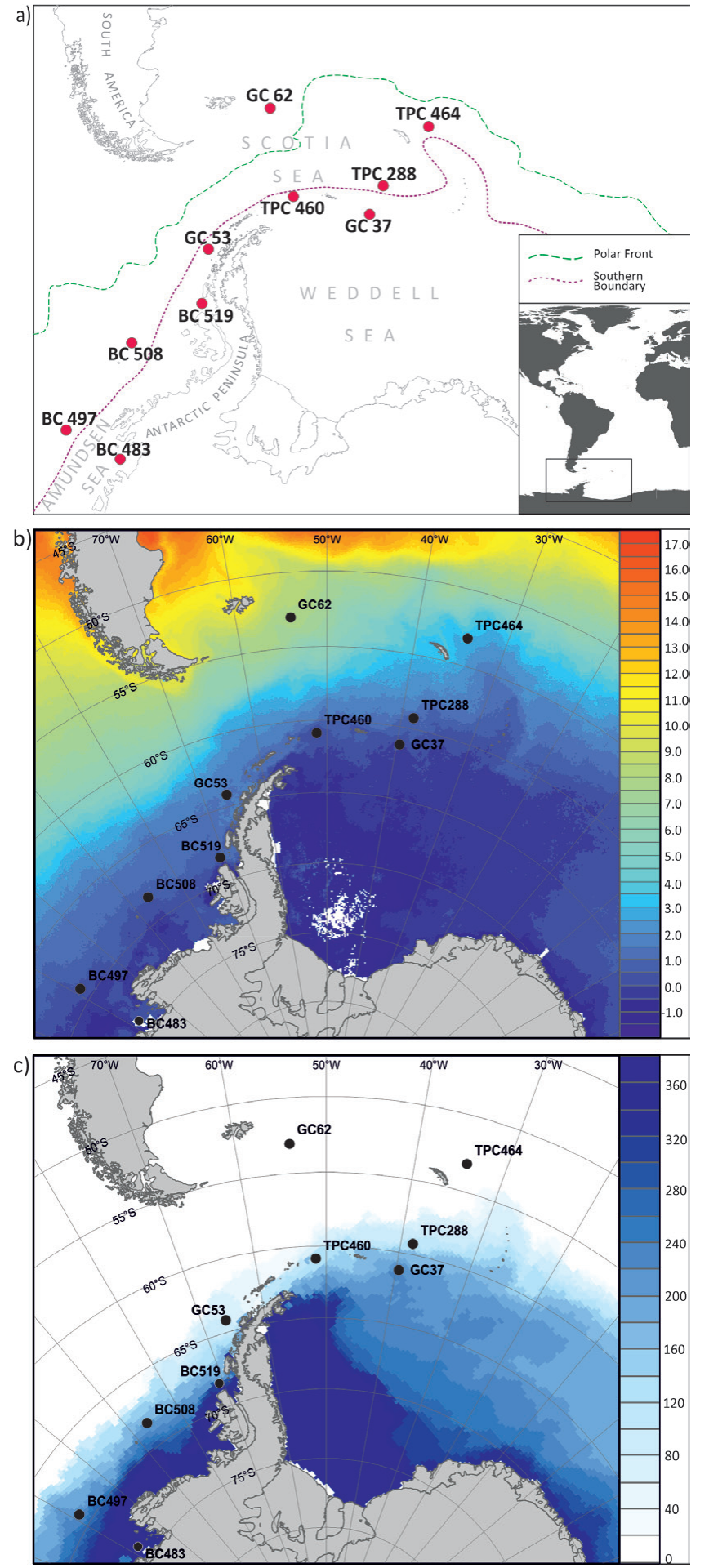

Fig. 2. Location maps. (a) Map of sample sites for Eucampia antarctica morphometric study. (b) Average summer sea surface temperatures (SST) for the Antarctic Peninsula region compiled from MODIS SST data.

The seasonal climatology comprises daily averaged data for the months of mid-December to mid-March for the years 2002 to 2012 (Feldman $\&$ McClain, 2012). (c) Mean sea-ice duration data (days per year) are calculated from daily remote-sensed readings that have been averaged into monthly mean values and then into a single grid for the period 1979-2007.
2002; Milliken et al. 2009), the ecological significance of E. antarctica's relative abundance remains ambiguous. The down-core pattern of E. antarctica's relative abundance is notably consistent throughout the Southern Ocean and Burckle (1984) shows how it provides a useful chronostratigraphic marker for glacial-interglacial time frames in Southern Ocean sediments where dating is often problematic. The temporal and spatial distribution of peak E. antarctica relative abundances led Burckle (1984) to propose that high abundances are associated with coastal conditions and melting icebergs, whilst Kaczmarska et al. (1993) and Whitehead et al. (2005) advocate a link with winter sea-ice extent. Burckle's (1984) assertion of a 'pseudoneritic' habitat for E. antarctica is gaining credence as authors recognize the potential links with nutrient (more specifically iron) availability and melt-waterinduced buoyancy (Mohan et al. 2006; Armand et al. 2008; Salter et al. 2012). Although I will briefly discuss the ecological implications of E. antarctica's pattern of relative abundance, the focus is primarily on assessing the morphological proxies.

In addition to the valve symmetry and colonial position of $E$. antarctica valves, the heights and widths of $E$. antarctica valves will be measured to assess whether or not the two morphological varieties exhibit distinct aspect ratios, as originally suggested by Fryxell (1991). Examining the data geographically, I will assess if there is a trend in the distribution of distinctively shaped valves and whether their distribution matches the trends of symmetry and colony structure already identified by previous authors or offers an independent facet of morphological diversity in E. antarctica valves.

\section{MATERIALS AND METHODS}

Box (BC), Trigger (TPC) and Gravity (GC) cores collected aboard the British Antarctic Survey vessel RRS James Clark Ross during research cruises to the Scotia Sea and AP between 1990 and 2008 were selected to represent a wide range of ocean and climate conditions in order to capture the greatest variability in morphological response. The ten core sites chosen for the study (GC 62, TPC 464, TPC 288, GC 37, TPC 460, GC 53, BC 519, BC 508, BC 497 and BC 483) span from north of the PFZ to the continental coast and cover a broad spectrum of temperature, light and sea-ice regimes (Fig. 2; Table 1).

Site GC 62 is in the SAZ at the western end of the Falkland Trough in waters $3000 \mathrm{~m}$ deep and is located north of both the maximum extent of sea-ice and the PFZ. TPC 464 is also situated north of the maximum sea-ice limit but lies within the present day PFZ. The majority of the cores (TPC 288, GC 37, TPC 460, GC 53, BC 519; BC 508 and BC 497) are all south of the PFZ with varying exposure to seasonal sea-ice and covering a depth range from $495 \mathrm{~m}$ to $4229 \mathrm{~m}$. BC 483 lies furthest to the south and closest to continental Antarctica (Fig. 2; Table 1). Sediments from the sites comprise diatom-bearing muds and diatomaceous muds, with varying contributions of foraminifera, radiolarians and sponge spicules. Terrigenous content is highest close to the continent at sites BC 483 and BC 519 and lowest at sites in the central Scotia Sea and NE Georgia Rise - TPC 288 and TPC 464.

Surface sediment samples from each of the cores were analysed for diatom assemblages and Eucampia antarctica morphometric data. Sediments were dried thoroughly in a warm oven at c. $30{ }^{\circ} \mathrm{C}$; then $5-200 \mathrm{mg}$ of bulk sediment was sub-sampled into 
Table 1. List of core samples with associated geographical and environmental data referred to in the text

\begin{tabular}{|c|c|c|c|c|c|c|}
\hline Core & Latitude & Longitude & Water depth (m) & Core length (m) & Summer SST $\left({ }^{\circ} \mathrm{C}\right)$ & Sea-ice cover (days per year) \\
\hline TPC 464 & -53.0452 & -34.0048 & 3028 & 9.27 & 3.5 & 0 \\
\hline GC 37 & -61.105 & -39.1783 & 4025 & 4.07 & -0.5 & $200-220$ \\
\hline ТPC 460 & -60.80914 & -51.03374 & 2592 & 0.68 & 0.0 & $120-140$ \\
\hline GC 53 & -64.1367 & -65.775 & 495 & 0.4 & 1.5 & $80-100$ \\
\hline BC 508 & -68.3105 & -86.0322 & 3560 & 0.295 & 0.0 & $200-220$ \\
\hline BC 497 & -69.2302 & -108.3492 & 4229 & 0.385 & 0.0 & $220-240$ \\
\hline BC 483 & -73.9915 & -107.3842 & 528 & 0.55 & -1.5 & $340-360$ \\
\hline
\end{tabular}

$30 \mathrm{ml}$ vials; these samples were cleaned and disaggregated using hydrogen peroxide $(30 \%)$, dilute hydrochloric acid and Calgon solution for a minimum of $12 \mathrm{~h}$ in a water bath at c. $50{ }^{\circ} \mathrm{C}$. Quantitative slides were prepared following the method of Scherer (1994) and mounted using Norland Optical Adhesive (refractive index $=1.56$ ). Assemblage and morphological counts were measured at $\times 1000$ magnification on an Olympus $\mathrm{BH} 2$ Light Microscope with $\times 10$ magnification eye pieces and an Olympus $\mathrm{S}$ Plan $\times 100$ oil immersion lens. Diatom concentrations (valves per gram of dry sediment) were calculated using the following equation after Scherer (1994):

$$
T=\frac{(N B / A F)}{M},
$$

where $N$ is the number of valves counted, $B$ is the area of beaker $\left(\mathrm{mm}^{2}\right), A$ is the area of transect $\left(\mathrm{mm}^{2}\right), F$ is the number of transects counted and $M$ is the mass of dried sample $(\mathrm{g})$.

Assemblage counts $(n \geq 300)$ were used to determine the relative abundance of E. antarctica in each sample. A minimum of 100 specimens of $E$. antarctica in each sample were categorized (intercalary or terminal) and the height of both 'horns' (sides) and the basal width measured on each valve for morphological analyses. Morphometric measurements were carried out only on complete winter stage valves of E. antarctica in broad girdle view to avoid any bias from different morphological responses between vegetative and winter form cells. As some discrepancy in measuring the diatom frustules in $2 \mathrm{D}$ is possible, all valves exhibiting a height difference between the two 'horns' (sides) of $\leq 2 \mu \mathrm{m}$ were classed as symmetrical and only once a height difference of $>2 \mu \mathrm{m}$ was exceeded were valves considered asymmetrical. These criteria hopefully ensure that symmetrical valves lying askew were not miscounted as asymmetrical. It is unlikely that valves with $<2 \mu \mathrm{m}$ height difference are capable of producing the tightly spiralling colonies that characterize E. antarctica var antarctica and may represent an intermediate, transitional form. Even so, the number of 'asymmetrical valves' in each sample is likely to be under-represented and reflects the minimum contribution of asymmetrical valves to a sample.

In order to assess the changes in aspect ratio between the samples, the broad girdle (basal) width and valve volumes were used to explore the statistical significance of the aspect ratio variability. The valve volume $(V)$ was calculated using the following equation:

$$
V=\pi a b h
$$

where $a$ is half of the narrow girdle width, $b$ is half of the broad girdle width and $h$ is the averaged valve height.

Fryxell (1991) shows that the narrow girdle width is typically between 16 and $20 \mu \mathrm{m}$ irrespective of the broad girdle width. As such, it is unlikely that this parameter has much influence on the changes in valve volume. As it is not possible to measure the narrow girdle width $(a)$ with valves orientated in broad girdle view, I have assumed a set value of $18 \mu \mathrm{m}$ as the narrow girdle width for all valves based on the measurements made by Fryxell (1991).

\section{RESULTS}

\section{Bulk diatom concentrations and assemblage composition}

Diatom absolute abundance in the surface sediments of the Scotia Sea and AP ranges from $<10 \times 10^{6}$ valves per gram of dry sediment (v/gds) to $>300 \times 10^{6} \mathrm{v} /$ gds (Fig. 3a; Table 2). Highest diatom concentrations of $327 \times 10^{6} \mathrm{v} / \mathrm{gds}$ and $298 \times 10^{6} \mathrm{v} / \mathrm{gds}$ are found in the surface samples from TPC $460 \&$ TPC 288, sites that lie within the seasonal sea-ice zone of the southern Scotia Sea and away from the continent. The next highest concentration of $222.2 \times 10^{6} \mathrm{v} / \mathrm{gds}$ occurs at site TPC 464, another site away from continental influences but north of the normal Scotia Sea seasonal sea-ice extent. Lowest diatom concentrations of $9.5 \times 10^{6} \mathrm{v} / \mathrm{gds}$ and $7.9 \times 10^{6} \mathrm{v} / \mathrm{gds}$ are found at sites GC 62 and BC 483, respectively. These sites are at opposite ends of the latitudinal range of this study and exposed to very different oceanographic conditions: GC 62 is from the southeastern flank of the Falkland Plateau in the SAZ whilst BC 483 is from Pine Island Bay, c. $230 \mathrm{~km}$ offshore from Pine Island Glacier. BC 508, from the deep Bellingshausen Sea, also contains relatively low diatom concentrations of $11.4 \times 10^{6} \mathrm{v} / \mathrm{gds}$. Of the remaining sites, diatom concentrations at GC 37, GC 53 and $\mathrm{BC} 497$ average $83.2( \pm 3.7) \times 10^{6} \mathrm{v} / \mathrm{gds}$ and concentrations reach $108.5 \times 10^{6} \mathrm{v} / \mathrm{gds}$ at site BC 519 in Marguerite Bay, west AP.

Diatom assemblage compositions of the surface sediment samples are comprised of one or two dominant species or species groups and other minor taxa (Table 2). Chaetoceros resting spore is the most common dominant group present at all except the Amundsen Sea site (BC 497), with relative abundances ranging from 17.8$87.0 \%$. Fragilariopsis kerguelensis (O’Meara) Hustedt has relative abundances $>10 \%$ at six of the study sites whilst E. antarctica, $F$. curta (Van Heurck) Hustedt, Rhizosolenia antennata (Ehrenberg) 

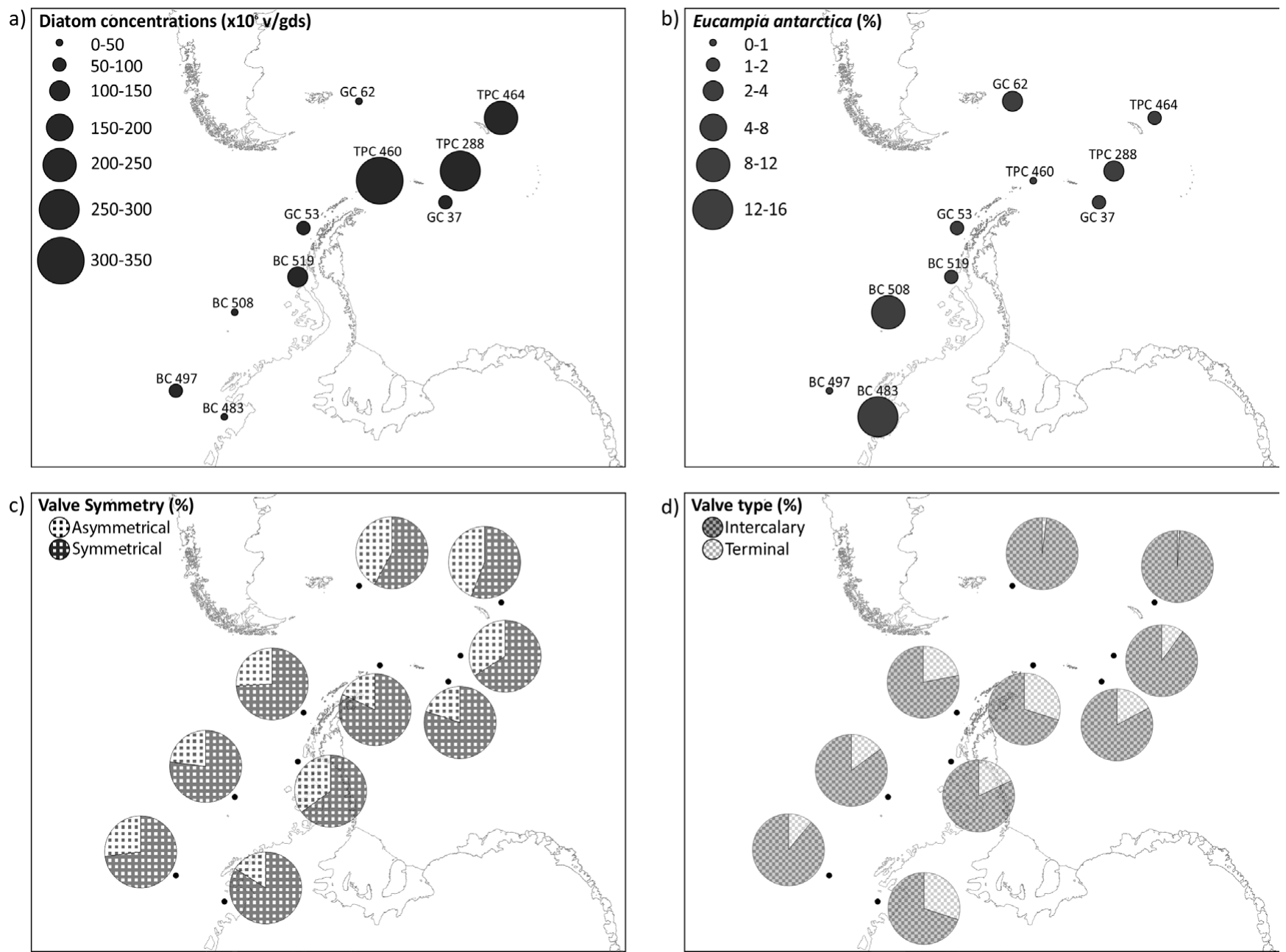

Fig. 3. Maps illustrating (a) diatom concentrations (b) relative abundance of Eucampia antarctica in surface sediment samples from the Scotia Sea and Antarctic Peninsula; and the relative contributions of (c) asymmetrical/symmetrical and (d) terminal/ intercalary valves to the Eucampia antarctica population in each sample.

Table 2. Diatom assemblage composition including total concentrations and relative contributions (\%) by major species

\begin{tabular}{|c|c|c|c|c|c|c|c|c|c|c|c|}
\hline Core & $\begin{array}{l}\text { Diatom conc. } \\
\left(\times 10^{6} \mathrm{v} / \mathrm{gds}\right)\end{array}$ & EUA & CRS & FKG & FCU & FCY & FOB & RHIA & TLENT & TANT & OTHER \\
\hline GC 62 & 9.4875 & 3.6 & 26.5 & 27.7 & 0.8 & 0.0 & 0.0 & 0.7 & 8.6 & 1.7 & 33.5 \\
\hline TPC 288 & 298.08 & 2.9 & 25.1 & 24.8 & 5.1 & 1.0 & 0.0 & 4.8 & 11.4 & 0.6 & 27.8 \\
\hline GC 37 & 81.969 & 1.6 & 46.8 & 11.9 & 2.0 & 3.1 & 0.5 & 10.4 & 3.1 & 1.3 & 23.9 \\
\hline ТPC 460 & 327.85 & $<0.3$ & 87.0 & 1.1 & 4.1 & 0.8 & 0.3 & 1.0 & 0.7 & 0.7 & 9.1 \\
\hline BC 508 & 11.361 & 8.9 & 17.8 & 36.1 & 2.5 & 0.0 & 0.0 & 0.0 & 2.5 & 1.0 & 37.1 \\
\hline BC 497 & 86.904 & 0.3 & 4.0 & 60.3 & 5.9 & 0.0 & 0.3 & 0.3 & 3.6 & 0.0 & 26.2 \\
\hline BC 483 & 7.9544 & 14.1 & 33.6 & 0.3 & 23.5 & 2.0 & 2.0 & 0.0 & 0.7 & 7.6 & 20.2 \\
\hline
\end{tabular}

EUA, Eucampia antarctica; CRS, Chaetoceros resting spores; FKG, Fragilariopsis kerguelensis; FCU, Fragilariopsis curta; FCY, Fragilariopsis cylindrus; FOB, Fragilariopsis obliquecostata; RHIA, Rhizosolenia antennata; TLENT, Thalassiosira lentiginosa; and TANT, Thalassiosira antarctica. Bold type indicates relative abundances of $>10 \%$. 
Table 3. Summary of morphometric data referred to in the text

\begin{tabular}{|c|c|c|c|c|c|c|c|c|}
\hline Core & SYM & ASYM & TERM & INT & SYM ratio & Colony ratio & $\begin{array}{c}\text { Mean basal width } \\
(\mu \mathrm{m})\end{array}$ & $\begin{array}{l}\text { Mean valve volume } \\
\qquad\left(\times 10^{3} \mu \mathrm{m}^{3}\right)\end{array}$ \\
\hline GC 62 & 58 & 42 & 2 & 98 & 0.72 & 0.02 & 30.7 & 7.49 \\
\hline ТРC 288 & 66 & 34 & 10 & 90 & 0.52 & 0.11 & 37.9 & 11.05 \\
\hline GC 37 & 80 & 20 & 17 & 82 & 0.25 & 0.21 & 36.2 & 11.42 \\
\hline ТPC 460 & 82 & 18 & 30 & 70 & 0.22 & 0.43 & 45.8 & 25.84 \\
\hline BC 508 & 77 & 23 & 15 & 85 & 0.30 & 0.18 & 35.1 & 11.07 \\
\hline BC 497 & 73 & 27 & 11 & 89 & 0.37 & 0.12 & 26.8 & 10.96 \\
\hline BC 483 & 84 & 16 & 30 & 70 & 0.19 & 0.43 & 52.4 & 19.93 \\
\hline
\end{tabular}

SYM, symmetrical valves; ASYM, asymmetrical valves; TERM, terminal valves; and INT, intercalary valves.

Table 4. Correlation coefficient $\left(r^{2}\right)$ values between environmental parameters and Eucampia antarctica valve characteristics

\begin{tabular}{lcccc}
\hline & Diatom conc. $\left(\times 10^{6} \mathrm{v} / \mathrm{gds}\right)$ & Latitude & Temperature (SST) & Sea-ice cover \\
\hline Diatom conc. $\left(\times 10^{6} \mathrm{v} / \mathrm{gds}\right)$ & - & 0.173 & 0.004 & 0.123 \\
EUA \% & $* 0.581$ & 0.253 & 0.059 & 0.214 \\
SYM ratio & 0.016 & 0.532 & $\mathbf{0 . 6 9 6}$ & 0.500 \\
Colony ratio & 0.003 & 0.371 & 0.467 & 0.347 \\
Mean basal width $(\mu \mathrm{m})$ & 0.004 & 0.239 & 0.207 & 0.364 \\
Mean valve volume $\left(\times 10^{3} \mu \mathrm{m}^{3}\right)$ & 0.071 & 0.176 & 0.218 & 0.277 \\
\hline
\end{tabular}

*Logarithmic regression (all others are linear). See Tables 2 and 3 for abbreviations. Bold type indicates the correlation with the highest significance.

Brown and Thalassiosira lentiginosa (Janisch) G. Fryxell all exhibit relative abundances $>10 \%$ at one or more of the study sites.

\section{Relative abundance of Eucampia antarctica}

$E$. antarctica is not the most dominant species in any of the surface sediments of the Scotia Sea and AP, comprising between $<0.3 \%$ and $14.1 \%$ of the total assemblage (Fig. 3b; Table 2). Although at first glance it appears that the pattern of E. antarctica relative abundances in the AP and Scotia Sea exhibits a northsouth trend, low percentages of E. antarctica at sites BC 497 and TPC 460 and the third highest relative abundance at site GC 62 are inconsistent with a north-south gradient of increasing relative abundance. The low correlation coefficient $\left(r^{2}=0.25\right.$; Table 4) reveals the disparity between $E$. antarctica relative abundances and latitude. Greater relative abundances of E. antarctica are, however, weakly correlated with decreasing valve concentrations $\left(r^{2}=0.58\right)$ (cf. Fig. 3a and b; Table 4). Highest relative abundances occur at sites TPC 483, BC 508 and GC 62 where sediments contain only $11.3 \times 10^{6} \mathrm{v} / \mathrm{gds}$ or less and E. antarctica comprises $14.1 \%, 8.9 \%$ and $3.6 \%$ of the assemblage, respectively (Fig. 3a and b). In contrast, lowest E. antarctica relative abundances of $<0.3 \%$ of the total diatom assemblage (being absent from the assemblage count of 300 valves) occur at site TPC 460 where diatom concentrations exceed $300 \times 10^{6} \mathrm{v} / \mathrm{gds}$.

\section{Morphology: symmetry and valve type}

The relative contributions of symmetrical and asymmetrical valves to the E. antarctica assemblages are stated in Table 3 and plotted in Figure 3c. Highest numbers of the asymmetrical E. antarctica var antarctica are found in the surface sediments from the Falkland Plateau and Northeast Georgia Rise (GC 62 and TPC 464) and the symmetrical E. antarctica var recta shows greatest dominance in samples of the northern Weddell Sea and southern AP (GC 37, TPC 460 and BC 483) (Fig. 3c). Asymmetrical valves comprise $42 \%$ and $44 \%$ of the $E$. antarctica assemblage in samples GC 62 and TPC 464, respectively, but only 16\%, 18\% and $20 \%$ in samples GC 37, TPC 460 and BC 483. Intermediate values between $20 \%$ and $40 \%$ asymmetrical valves occur in west AP and central Scotia Sea surface sediments at sites BC 497, BC 508, BC 519 and TPC 288. The highest proportion of symmetrical valves $(84 \%)$ occurs in sample BC 483 in the southern Amundsen Sea. Agglomerative hierarchical clustering (AHC) on these valve symmetry data reveals four groups of statistically similar samples (Fig. 4a).

The relative numbers of intercalary and terminal valves (Table 3; Fig. 3d) yield useful information about the chain structures of the E. antarctica colonies. Although intercalary valves outnumber the terminal valves in every sample, the greater the number of pointed or 'horned' terminal valves, the more prevalent are the shorter colonies of the polar E. antarctica var recta. In sample TPC 483, $30 \%$ of the specimens are terminal valves, whilst in TPC 464 and GC 62 the samples have only 1 and 2 terminal valves, respectively, so are made up almost entirely of intercalary valves. AHC on these terminal versus intercalary valve form data reveals three significant groups of cores with the third group being split into two further (insignificant) sub-groups (Fig. 4b).

There is a good correlation between the ratios of valve symmetry and valve type $\left(r^{2}=0.706\right)$ (cf. Fig. $3 \mathrm{c}$ and d) and the 
a)

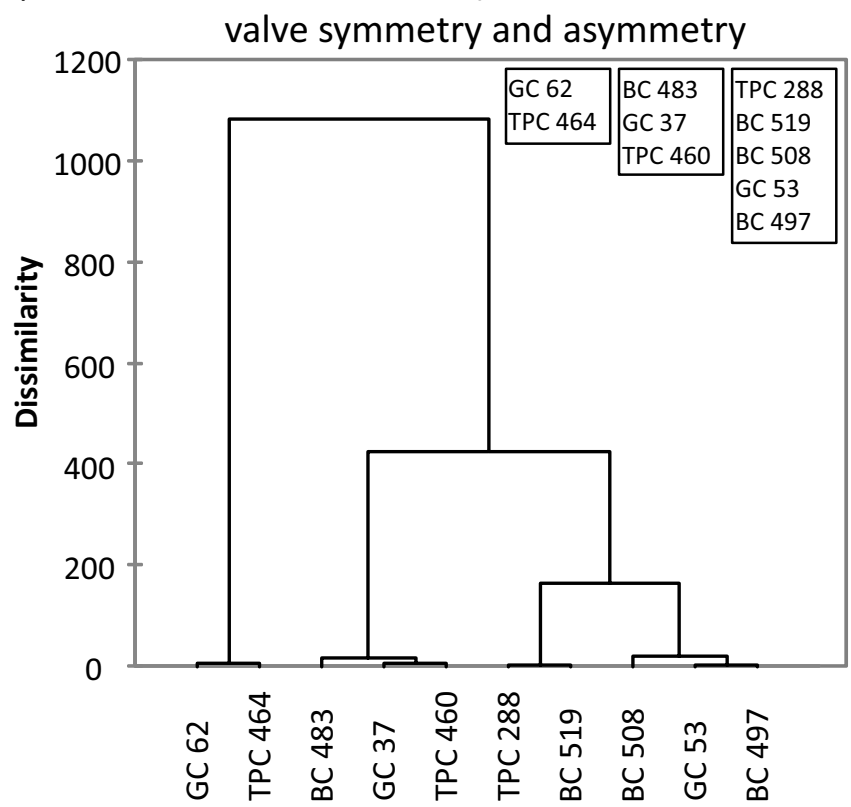

b)

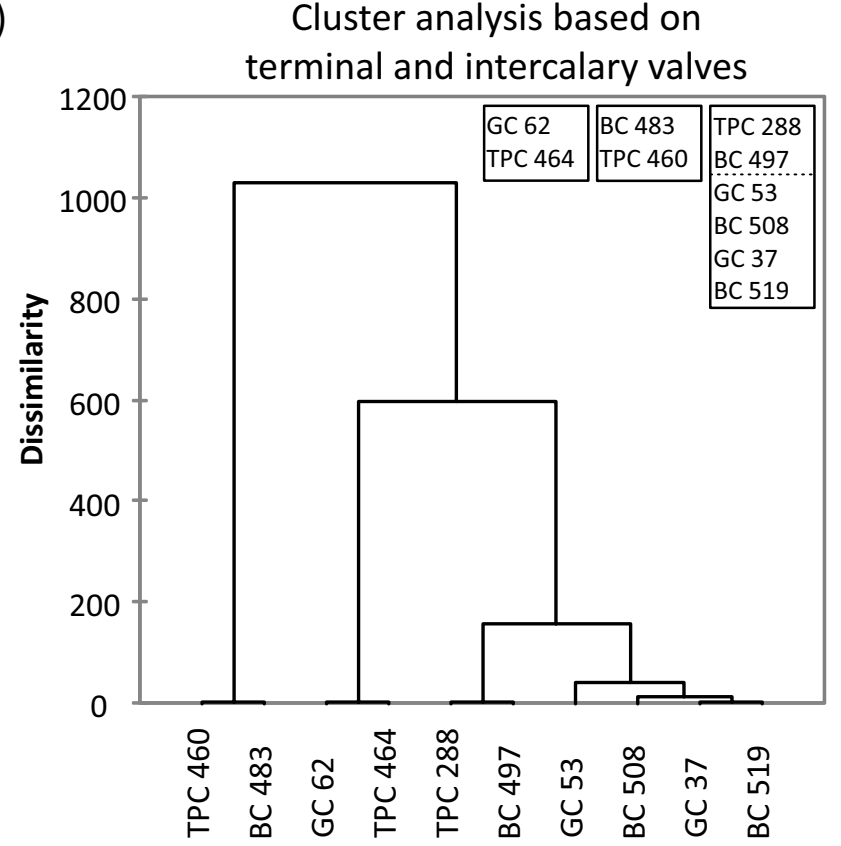

c)

\section{Cluster analysis based on} valve basal width

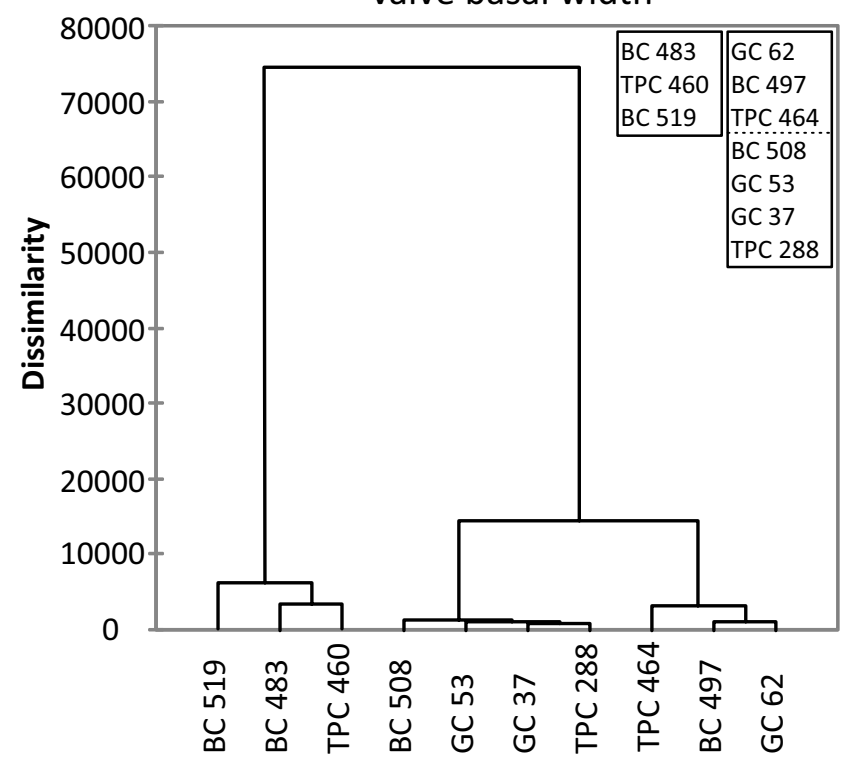

d)

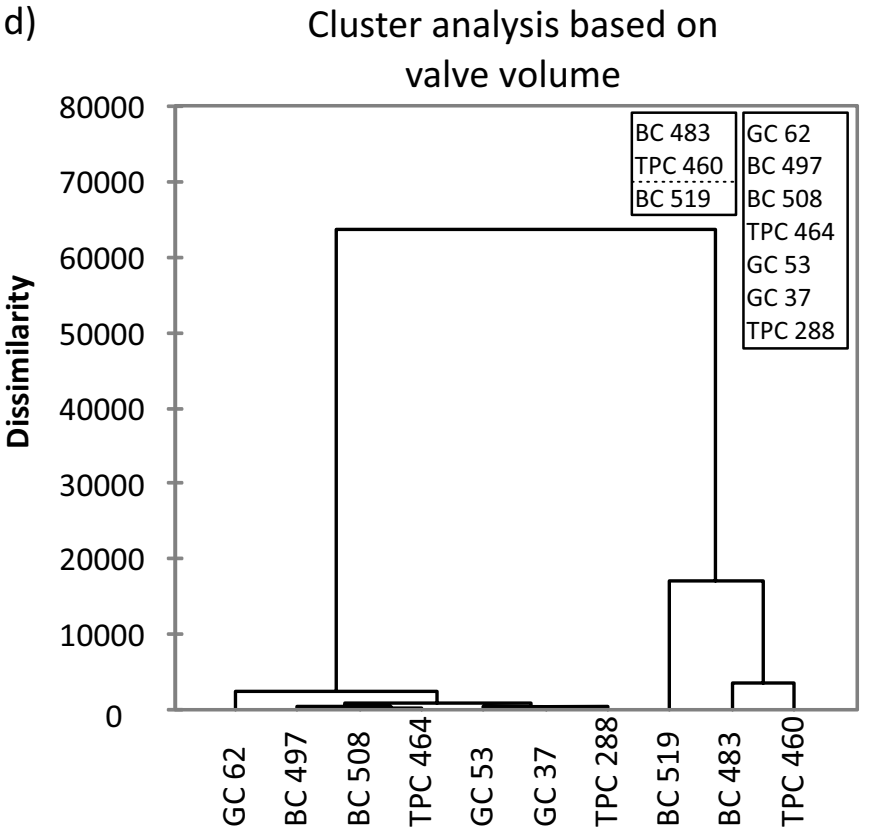

Fig. 4. Dendrograms presenting results of the agglomerative hierarchical clustering analysis on (a) the ratio of symmetrical versus asymmetrical Eucampia antarctica valves; (b) the ratio of terminal versus intercalary Eucampia antarctica valves; (c) the basal widths of Eucampia antarctica valves; and (d) the calculated volumes of Eucampia antarctica valves in surface sediment samples of the Scotia Sea and Antarctic Peninsula.

groupings revealed by the AHC on the two datasets are broadly consistent also (Fig. 4a and b).

\section{Morphology: aspect ratio}

The aspect ratio (width and average side height) of the 100 specimens measured in each sample are plotted as scattergrams (Fig. 5) to illustrate the morphological diversity within each sample. Cumulative frequency plots of the valve volumes are also included to illustrate the valve size distribution of each sample
(Fig. 6). All axes and plots are drawn at the same scale for ease of comparison.

There are clear differences in the valve shapes and in the range of sizes within a sample (Figs 5 and 6). Sample GC 62 exhibits the least variety in valve shape, with all valves measuring shorter than $30 \mu \mathrm{m}$, narrower than $60 \mu \mathrm{m}$ and having volumes of less than $15 \times 10^{3} \mu \mathrm{m}^{3}$ (Fig. 6). In contrast, BC 519 displays the greatest variety of shapes and sizes, with valve heights and widths ranging from $17-108 \mu \mathrm{m}$, and $17-116 \mu \mathrm{m}$, respectively, and with 


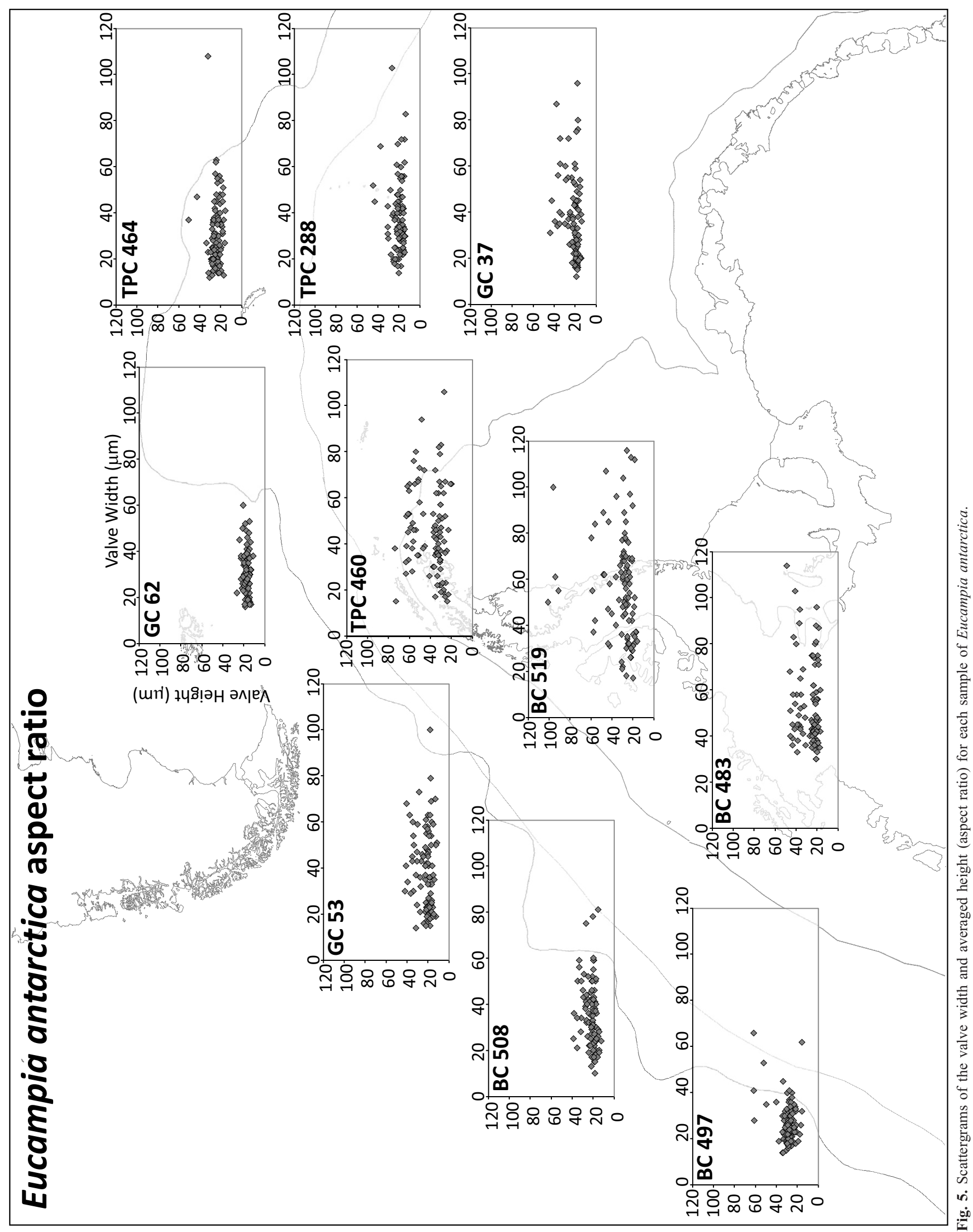




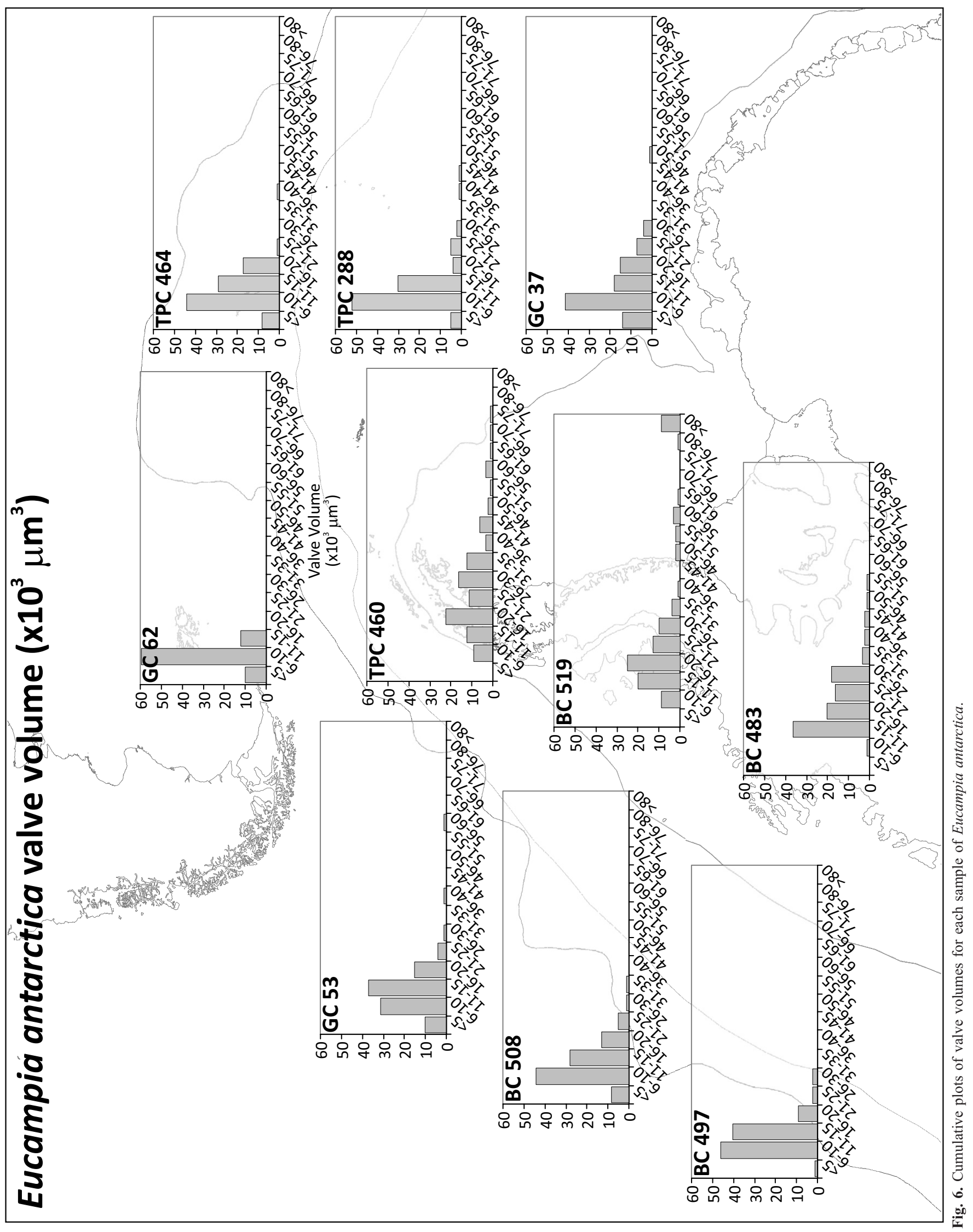


the highest valve volumes spanning from $5.91 \times 10^{3} \mu \mathrm{m}^{3}$ to $118.95 \times 10^{3} \mu \mathrm{m}^{3}$ (Fig. 6).

Across the Scotia Sea there is a north-south trend of increasingly diverse valve shapes from GC 62 to TPC 460. A similar trend is evident along the SW AP from BC 497, where valve shapes exhibit minimal diversity, to $\mathrm{BC} 519$ where the wide range of valve shapes and sizes is on a par with TPC 460 (Fig. 5; Table 1). All the remaining samples contain assemblages that evince intermediate size and shape variability.

AHC analysis on the basal widths (Fig. 4c) and valve volume (Fig. 4d) sorts the samples into two identical clusters comprised of TPC 460, BC 483 and BC 519 in one and the other 7 samples (GC 62, TPC 464, TPC 288, GC 37, GC 53, BC 508 and BC $497)$ in the second. In the AHC of basal widths the second cluster can be further subdivided into two groups: the first containing GC 62, TPC 497 and TPC 464 and the second containing TPC 288, GC 37, GC 53 and BC 508 (Fig. 4c). The AHC of valve volumes exhibits greater divergence between BC 483, TPC 460 and $\mathrm{BC}$ 519 (Fig. 4d).

An interesting feature of the basal width data from E. antarctica specimens is a disparity between site BC 483 and all other sites. Of the $100 \mathrm{E}$. antarctica valves measured in $\mathrm{BC} 483$ no basal widths are less than $30 \mu \mathrm{m}$, whilst minimum basal widths measure between 10 and $17 \mu \mathrm{m}$ at all the other sites presented here (Fig. 5).

\section{DISCUSSION}

\section{Bulk diatom concentrations and assemblage composition}

Diatom absolute abundances (concentration) in marine sediments are a function of production, preservation, dilution and lateral transportation. In surface sediments of the Scotia Sea and AP diatom concentrations are broadly consistent with the oceanographic setting at each of the sites. Low diatom concentrations at site GC 62 are probably due to its location north of the PFZ, beyond the Southern Ocean's 'opal belt' where exposure to silica-depleted waters inhibits diatom production and preservation. The position of site BC 483 in the southern Amundsen Sea results in low concentrations of diatoms in the sediment due to the short light-limited growth season at $74^{\circ}$ south, episodic years of permanent ice cover as well as greater dilution from high inputs of glacial flour and ice-rafted debris.

The highest concentrations of diatom valves in the sediments of TPC 460 and TPC 288 reflect their position within the seasonal sea-ice zone and close to the Southern Boundary of the Antarctic Circumpolar Current (Fig. 2). High export production derives from sea-ice melt-induced spring blooms and long summer-autumn growth seasons supported by nutrient-rich upper circumpolar deep water (CDW) along the Southern Boundary (Tynan, 1998). These sites are too shallow to be exposed to the influence of Si-reduced bottom water and are located in bathymetrically sheltered positions protected from strong currents, allowing accumulating sediments to be preferentially preserved.

In contrast, GC 37 has much lower absolute valve abundance in the surface sediments, readily explained once the regional oceanographic setting is considered. Here sea-ice is more persistent owing to the northern limb of the Weddell Gyre transporting cold waters and sea-ice into the area from the NW Weddell Sea (Fig. 2b and c), and the absence of CDW which fails to penetrate through the south Scotia Ridge. Site GC 37 is also deep enough to experience Si-depleted bottom waters exiting the Weddell Sea and may be exposed to winnowing currents (Carmack, 1973; Naveira Garabato et al. 2002).

\section{Relative abundance of Eucampia antarctica}

The weak inverse correlation between Eucampia antarctica relative abundance and diatom concentration may provide valuable clues to the ecology of E. antarctica. The highest relative abundance of $14.1 \%$ occurs in the surface sediments of BC 483 and suggests either that the oceanic setting is favourable for high production of E. antarctica or that production of other species is very poor at this southern site. The oceanographic conditions in the high latitude Amundsen Sea are dominated by sea-ice, icebergs and nearshore polynyas and are consistent with the initial concepts of E. antarctica's ecological associations (Burckle, 1984; Kaczmarska et al. 1993; Whitehead et al. 2005). Although the southern Amundsen Sea may support high production of E. antarctica, the low diatom concentrations at site $\mathrm{BC} 483$ are evidence of low diatom production, poor preservation and/or dilution with other (glacial) sediment sources, such that taphonomic conditions may explain the higher relative abundance of heavily silicified E. antarctica valves at the site. Similarly, the $3.6 \%$ E. antarctica present in the assemblage of GC 62 may also be a result of taphonomic alteration in the reduced silica waters of the SAZ rather than a reflection of better growth conditions in the surface waters. It is difficult to reconcile the pattern of relative abundances without a better understanding of the flux of valves from the surface or the ecological preferences of E. antarctica.

\section{Morphology: colony structure (symmetry and valve type)}

The distribution of symmetrical and terminal valves versus asymmetrical and intercalary valves in surface sediments of the SW Atlantic and AP (Fig. 3c and d) follows a broad north-south trend that corresponds well with water temperature in the region (Fig. 2b). GC 62 and TPC 464 are both located within the SAZ and PFZ beyond the influence of seasonal sea-ice (Fig. 2c) and where summer SSTs are typically between 3 and $7^{\circ} \mathrm{C}$ (Fig. 2b). Consistent with the relatively warm SST at these sites, they contain the highest percentage of the asymmetrical valve forms and least number of terminal valves, reaffirming the association of long, spiralling chains of E. antarctica var. antarctica with the warmer conditions of the PFZ and SAZ as originally proposed by Fryxell (1991) and supported by Kaczmarska et al. (1993) and Scherer et al. (2008).

In contrast, BC 483 and TPC 460 contain the highest ratio of symmetrical and terminal valves within these morphometric data, reflecting the cold summer SSTs of $<0.5^{\circ} \mathrm{C}$ that characterize the Amundsen Sea embayment and the NW Weddell Sea (Fig. 2b).

TPC 288's valve morphological variety is consistent with its location within the seasonal sea-ice zone (Fig. 2c) but north of the South Boundary where circumpolar waters $\left(>1.0^{\circ} \mathrm{C}\right)$ of the Antarctic Circumpolar Current are prevalent (Fig. 2b) and probably represents a mix of the var. recta and var. antarctica valves or a transitional form.

BC 519's morphological assemblage differs from the other sites on the AP, having fewer symmetrical and terminal valves and suggesting a warmer environment than would be expected for its location on the AP inner shelf pattern. The pattern is consistent in both symmetry and colony length and may be explained by the 
modern intermittent upwelling of CDW along the Marguerite Bay Trough and/or thermal stratification that would yield localized ocean warming.

The AHC analyses of valve symmetry and valve form yield very similar sample groupings in each to the two sets of data (Fig. 4a and b) adding weight to the premise that both valve symmetry and valve shape respond to the same forcing conditions. The distribution pattern of short, straight-sided colonies inhabiting colder, continental sites and the longer, spiralling colonies in the relatively warmer, permanently open Antarctic and sub-Antarctic waters is consistent throughout the Scotia Sea and AP and adds further legitimacy to this morphological change being a reliable proxy for relative temperatures. Linear regression between average summer SST and the ratios of symmetry and valve type delivers $r^{2}$ values of 0.696 and 0.467 , respectively (Table 4), showing that the ratio of symmetrical to asymmetrical valves is a more accurate proxy for temperature than colony length. The strength of this relationship may be improved if it were possible to distinguish asymmetrical valves accurately, irrespective of their orientation on the slide. The regression analysis also suggests that with additional data points there is scope to develop a quantitative proxy based on the ratio of valve symmetry. A quantitative proxy for SSTs down to $-1.5^{\circ} \mathrm{C}$ would be a valuable tool as most existing temperature proxies are either poorly calibrated for the Antarctic region or unable to resolve changes at low temperature.

\section{Morphology: aspect ratio}

The range of valve aspect ratios in the E. antarctica samples from the Scotia Sea and AP do not match the distribution pattern of valve symmetry. In particular, the three sites on the WAP outershelf - BC 497, BC 508 and GC 53 - exhibit a west-east trend of increasing diversity in E. antarctica's aspect ratio (Fig. 5), whilst the ratio of symmetrical to asymmetrical valves are broadly consistent across all three sites (Fig. 3c). These inconsistencies in size and shape distribution suggest that temperature is not the principal factor driving changes in aspect ratio. The AHC results yield groupings for basal widths and valve volume which are noticeably different from those for valve symmetry and valve type (cf. Fig. 4a and d) and add weight to the suggestion that an alternative forcing mechanism (not temperature) lies behind the variety and distribution of valve shape evident in these aspect ratio data.

Linear regression analyses between mean basal width and mean valve volume against temperature and sea-ice cover yield fairly low $r^{2}$ values of $0.207,0.364$ and $0.218,0.277$ (Table 4) and provide further evidence that the aspect ratios are not sensitive to either temperature or sea-ice cover.

Although I show that temperature and sea-ice cover do not provide a straightforward explanation for the distribution of valve shapes found in the Scotia Sea and AP surface sediments, there are many other environmental parameters and biological responses that could account for changes in aspect ratio. Comparing the locations of the AHC-defined group of samples with the leastvaried aspect ratios (GC 62, BC 497 and TPC 464; Fig. 4c and d), it is immediately apparent that these sites are located in open ocean sites, far from continental influences (Fig. 2). Oceanographically this translates as distance away from inputs of terrigenous material, greater water column mixing, potentially less exposure to grazing pressures with distance north of the Southern Boundary (Tynan, 1998) and reduced iceberg concentration. These oceanographic conditions yield low nutrient inputs from terrestrial sources (iron?), increase mixed-layer depth and may flush cells beyond their irradiance limit. Alternatively, the AHC-defined group of three samples containing the most diverse valve shapes (BC 483, BC 460 and BC 519; Fig. 4c and d) are all within the seasonal sea-ice zone and much closer to the Antarctic continent (Fig. 2). These locations are likely to be characterized by high fluxes of glacial debris and icebergs, short growth seasons associated with stratified waters induced from sea-ice or glacier melt and episodic high productivity events associated with polynya or open-water formation driven by katabatic offshore winds.

From the descriptions of the broad oceanographic settings of the two groups (high and low diversity in aspect ratio), it is apparent that there are several environmental gradients that may potentially account for the observed variability in E. antarctica aspect ratio: input of terrigenous material; melt water flux; stratification and light intensity/availability. However, without better quantification of these parameters it is impossible to ascertain which, if any, of these environmental features may determine $E$. antarctica aspect ratio.

\section{CONCLUSIONS}

This paper expands on previously published data on Eucampia antarctica polymorphism and presents morphometric data covering the full range of cell structures and aspect ratio found in the surface sediments of the Scotia Sea and Antarctic Peninsula. Comparison of cell symmetry and colony length as proxies for temperature has shown that the ratio of cell symmetry is a more reliable temperature proxy than the ratio of terminal to intercalary valves. Augmenting the data presented here to include more samples from within the $-1.5^{\circ} \mathrm{C}$ to $8^{\circ} \mathrm{C}$ temperature range would be useful in determining whether the match between valve symmetry and sea surface temperature is consistent enough to establish a new quantitative austral summer SST proxy for Antarctic waters.

As well as providing a more thorough grounding for existing proxies, the paper has also examined the aspect ratio as a new facet of E. antarctica polymorphism. Although the data show that the aspect ratio of the E. antarctica populations does not correlate with either temperature or sea-ice, this may be considered a positive result for proxy development. Comparison with other environmental data may reveal the factor controlling morphological divergence in E. antarctica's aspect ratio and offer the potential for a novel proxy.

\section{ACKNOWLEDGEMENTS}

This study is part of the British Antarctic Survey (BAS) Chemistry and Past Climate Programme, which is a component of the BAS strategic science framework Polar Science for Planet Earth and was funded by The Natural Environment Research Council. I am grateful to the Officers, crew and science parties of the RRS Discovery and the RRS James Clark Ross on the science cruises D 172, JR 04, JR 48, JR 149 and JR 179 for their support in collecting the core material used in this study. Thanks to $\mathrm{H}$. Blagbrough, T. Galton and C. Cook for some of the slide preparation and morphological counts included in this study and to $\mathrm{P}$. Fretwell and A. Fleming of the BAS mapping department for their kind assistance with Figure 2. Thanks also to A. Leventer and an 
anonymous reviewer for their supportive and constructive comments on the submitted manuscript and to J. Pike, R. Jordan and other diatom colleagues for insightful and varied discussions on diatom morphology.

\section{Manuscript received 31 August 2013 Manuscript accepted 7 October 2013 Scientific editing by Taniel Danelian}

\section{REFERENCES}

Armand, L.K., Cornet-Barthaux, V., Mosseri, J. \& Quéguiner, B. 2008. Late summer diatom biomass and community structure on and around the naturally iron-fertilised Kerguelen Plateau in the Southern Ocean. Deep Sea Research Part II: Topical Studies in Oceanography, 55: 653-676.

Balzano, S., Sarno, D. \& Kooistra, W.H.C.F. 2011. Effects of salinity on the growth rate and morphology of ten Skeletonema strains. Journal of Plankton Research, 33: 937-945.

Beszteri, B., John, U. \& Medlin, L.K. 2007. An assessment of cryptic genetic diversity within the Cyclotella meneghiniana species complex (Bacillariophyta) based on nuclear and plastid genes, and amplified fragment length polymorphisms. European Journal of Phycology, 42: 47-60.

Bruder, K. \& Medlin, L.K. 2008. Morphological and molecular investigations of Naviculoid diatoms II. Selected genera and families. Diatom Research, 23: 283-329.

Buffen, A., Leventer, A., Rubin, A. \& Hutchins, T. 2007. Diatom assemblages in surface sediments of the northwestern Weddell Sea, Antarctic Peninsula. Marine Micropaleontology, 62: 7-30.

Burckle, L.H. 1984. Ecology and paleoecology of the marine diatom Eucampia antarctica (Castr.) Mangin. Marine Micropaleontology, 9: $77-86$.

Carmack, E.C. 1973. Silicate and potential temperature in the deep and bottom waters of the western Weddell Sea. Deep Sea Research and Oceanographic Abstracts, 20: 927-932.

Cattaneo, A., Couillard, Y., Wunsun, S. \& Courcelle, M. 2004. Diatom taxonomic and morphological changes as incubators of metal pollution and recovery in Lac DuFault (Québec, Canada). Journal of Paleolimnology, 32: 163-175.

Cortese, G. \& Gersonde, R. 2007. Morphometric variability in the diatom Fragilariopsis kerguelensis: Implications for Southern Ocean paleoceanography. Earth and Planetary Science Letters, 257: 526-544.

Doucette, G.J. \& Fryxell, G.A. 1985. Thalassiosira antarctica (Bacillariophyceae) - Vegetative and resting stage ultrastructure of an ice-related marine diatom. Polar Biology, 4: 107-112.

Feldman, G.C. \& McClain, C.R. 2012. MODIC Reprocessing. In Kuring, N. \& Bailey, S.W. (Eds), Ocean Color Web. NASA Goddard Space Flight Center.

Fryxell, G.A. 1988. Polymorphism in relation to environmental conditions as exemplified by clonal cultures of Thalassiosira tumida (Janisch) Hasle. In Round, F.E. (Ed.), 9th International Diatom Symposium Proceedings. Biopress Ltd, Bristol \& Koeltz, Koenigstein, 61-73.

Fryxell, G.A. 1991. Comparison of winter and summer growth stages of the diatom Eucampia antarctica from the Kerguelen Plateau and south of the Antarctic Convergence Zone. In Barron, J.A., Larsen, B. \& 28 others, Proceedings of the Ocean Drilling Programme, 119: 675-685. Ocean Drilling Programme, College Station, TX.

Fryxell, G.A. 1994. Planktonic marine diatom winter stages: antarctic alternatives to resting stages. 11th Diatom Symposium. California Academy of Sciences, 437-448.
Fryxell, G.A. \& Prasad, A.K.S.K. 1990. Eucampia antarctica var. recta (Mangin) stat. nov. (Biddulphiaceae, Bacillariophyceae): Life stages at the Weddell Sea ice edge. Phycologia, 29: 27-38.

Ishii, K.-I., Iwataki, M., Matsuoka, K. \& Imai, I. 2011. Proposal of identification criteria for resting spores of Chaetoceros species (Bacillariophyceae) from a temperate coastal sea. Phycologia, 50: 351-362.

Kaczmarska, I., Barbrick, N.E., Ehrman, J.M. \& Cant, G.P. 1993. Eucampia Index as an indicator of the Late Pleistocene oscillations of the winter sea-ice extent at the ODP Leg 119 Site 745B at the Kerguelen Plateau. Hydrobiologia, 269/270: 103-112.

Leventer, A., Domack, E., Barkoukis, A. et al. 2002. Laminations from the Palmer Deep: a diatom-based interpretation. Paleoceanography, 17: $1-15$.

Ligowski, R., Jordan, R. \& Assmy, P. 2012. Morphological adaptation of a planktonic diatom to growth in Antarctic sea ice. Marine Biology, 159: $817-827$.

Milliken, K.T., Anderson, J.B., Wellner, J.S., Bohaty, S.M. \& Manley, P. L. 2009. High-resolution Holocene climate record from Maxwell Bay, South Shetland Islands, Antarctica. Geological Society of America Bulletin, 121: 1711-1725.

Mohan, R., Shanvas, S., Thamban, M. \& Sudhakar, M. 2006. Spatial distribution of diatoms in surface sediments from the Indian sector of Southern Ocean. Current Science, 91: 1495-1502.

Naveira Garabato, A.C., Heywood, K.J. \& Stevens, D.P. 2002. Modification and pathways of Southern Ocean deep waters in the Scotia Sea. Deep Sea Research Part I: Oceanographic Research Papers, 49: 681-705.

Paasche, E., Johansson, S. \& Evensen, D.L. 1975. An effect of osmotic pressure on the valve morphology of the diatom Skeletonema subsalsum (A. Cleve) Bethge. Phycologia, 14: 205-211.

Palmisano, A.C. \& Sullivan, C.W. 1983. Physiology of sea ice diatoms. II. Dark survival of three polar diatoms. Canadian Journal of Microbiology, 29: 157-160.

Peters, E. \& Thomas, D.N. 1996. Prolonged nitrate exhaustion and diatom mortality: A comparison of polar and temperate Thalassiosira species. Journal of Plankton Research, 18: 953-968.

Poulíčková, A. \& Hašler, P. 2007. Aerophytic diatoms from caves in central Moravia (Czech Republic). Preslia, 79: 185-204.

Salter, I., Kemp, A.E.S., Moore, C.M., Lampitt, R.S., Wolff, G.A. \& Holtvoeth, J. 2012. Diatom resting spore ecology drives enhanced carbon export from a naturally iron-fertilized bloom in the Southern Ocean. Global Biogeochemical Cycles, 26: GB1014.

Scherer, R.P. 1994. A new method for the determination of absolute abundance of diatoms and other silt-sized sedimentary particles. Journal of Paleolimnology, 12: 171-179.

Scherer, R.P., Bohaty, S.M. \& Dunbar, R.B. \& 6 others. 2008. Antarctic records of precession-paced insolation-driven warming during early Pleistocene Marine Isotope Stage 31. Geophysical Research Letters, 35, L03505.

Taylor, F. \& Sjunneskog, C. 2002. Postglacial marine diatom record of the Palmer Deep, Antarctic Peninsula (ODP Leg 178, Site 1098) 2. Diatom assemblages. Paleoceanography, 17: PA8001.

Tynan, C.T. 1998. Ecological importance of the Southern Boundary of the Antarctic Circumpolar Current. Nature, 392: 708-710.

Villareal, T.A. \& Fryxell, G.A. 1983. Temperature effects on the valve structure of the bipolar diatoms Thalassiosira antarctica and Porosira glacialis. Polar Biology, 2: 163-169.

Whitehead, J.M., Wotherspoon, S. \& Bohaty, S.M. 2005. Minimal Antarctic sea ice during the Pliocene. Geology, 33: 137-140. 